that the now declining costs of the Space Shuttle development programme gives the administration "the flexibility to give greater attention to new space applications and exploration, continue programs at present levels, or contract them." Funds to cover these will be "adequate."

Turning to space science, the president says that in addition to continuing a vigorous programme of planetary explorations to understand the origin and evolution of the solar system, the US will utilise the space telescope and free-flying satellites to usher in "a new era of astronomy" which will include the exploration of interstellar molecules, quasars, pulsars and black holes.

The most controversial part of the statement comes in the section covering space applications, and in particular the future direction of earth monitoring systems such as LANDSAT. The administration has been under Congressional pressure for some time to come up with a clear set of policy goals and long-term objectives.

Last month, for example, Senator Adlai Stevenson, chairman of the Senate subcommittee on science and space, introduced a bill which would require the president to present Congress annually with a five year forwardplan clearly laying out the administration's space objectives and how it proposed to meet them.

However, so far the administration has backed away from any firm commitment of this nature. And last week's statement merely says that, in the case of remote sensing systems, NASA will chair an interagency task force "to examine options" for an integrated system, and that a comprehensive plan covering all aspects of remote sensing "will be explored."

\title{
World climate conference thrown open to social scientists
}

WHEN the World Climate Conference meets in Geneva in February next, it will involve some 400 participants instead of the 100 or so originally envisaged by its organisers at the World Meteorological Organisation (WMO). So now the social as well as the physical sciences can be represented - a move in line with the new trend of thinking on the role of science in the United Nations system. This broader participation also underlines the main objective of the conference "to examine the impact of climate on various aspects of human welfare, and especially of climatic fluctuations on all time scales".

WMO's Secretary General Dr D. A. Davies points out that the effects of cold spells and droughts have in recent years presented grave problems affecting energy supplies and agricultural output even in the most highly developed countries. At the other end of the economic ladder, the effects of the disaster caused originally by the drought in the Sahel in the early 1970 s are still causing grave concern. So this effort to bring about a "meeting of the minds" between the meteorologists and the behavioural scientists, biologists, economists and others in relevant disciplines is certainly not being made a moment too soon.

Nevertheless no great scientific surprises are expected to emerge from next February's meeting. As WMO sees it, hard evidence does little to support many of the disaster hypotheses of the doom-watchers. It is admitted, however, that there is one major exception: the problem of increasing $\mathrm{CO}_{2}$ in the atmosphere. This is something in which WMO is seriously engaged, and is considered important enough for a major global effort to be made in the immediate future: the proposal is to use a wide network of regional observing stations, together with a smaller number of permanent baseline stations sited so as to cover the whole of the Earth's surface.

Peter Collins

\section{ICSU investigates refused visas}

ICSU the International Council of Scientific Unions-is to investigate the complaint of a group of Israeli geneticists who failed to receive visas for the fourteenth International Congress of Genetics, held in Moscow last August.

Originally, 33 members of the Israeli Society of Genetics registered for the congress and received a registration number, indicating that their application was accepted. However, a month before the congress, visas had not yet arrived.

On 10 August, the Israeli Society of Genetics cabled Professor Ralph Riley, secretary of the International Genetics Federation, suggesting that the federation withdraw its sponsorship of the congress. This, it appeared, was impossible, both because the federation was financially committed, and also because it was feared such an action would "throw Russian genetics into turmoil again".

Eventually 18 visas arrived - restricted to the exact dates and place of the congress and with no provision for accompanying spouses nor for participation in the traditional post-congress excursions. At this the Israeli Society of Genetics decided to recommend its members not to attend-a recommendation which was duly followed. Instead, two delegates attended to put the Israeli case formally.

After various unofficial discussions, the case was raised at the representative council of the federation, and a resolution was passed, mild in tone, but demanding that "steps should be taken to ensure that all applicants to further congresses receive their visas in due time".

Last month, when the ICSU general assembly met in Athens, the resolution was brought to the attention of the Committee for the Free Circulation of Scientists. The Committee, which includes among its membership a representative of the Soviet Academy of Sciences, has undertaken to look into the matter.

Vera Rich

\section{"Erosion of spirit" in British science}

THE morale of academic research scientists in British universities is at a low ebb, according to the Trustees of the Nuffield Foundation, a British charitable organisation which supports university research.

Writing in the annual report of the foundation, the trustees claim to observe "what appears to be an erosion of the spirit in scientific and medical research at British universities and polytechnics". The trustees base this

assertion on the fact that the Nuffield Foundation "has received many fewer applications of high quality for research grants in science and medicine than would have been expected if university departments were bursting with ideas and needing only financial resources to carry them through". The morale of the younger members of the community is particularly affected, says the report.

The trustees select lack of growth in the universities as the main culprit: "younger people... can no longer set their sights on what until quite recently was the chief objective of young creative scientists-to be so successful in their chosen field as to make a mark not only in the scientific literature but on the pattern of research in their institutions."

The foundation offers to help-if anyone can come up with a practical proposal. 